\title{
Ang. Hölderlin
}

Hölderlins "Brot und Wein" er anledningen til den sektion, der afslutter dette nummer af PASSAGE. Eller måske er det snarer "Brød og vin", ligeledes af Hölderlin, der fungerer som det fælles omdrejningspunkt for de tre bidragydere Thorkild Bjørnvig, Per Aage Brandt og Jørn Erslev Anderrsen.

Forrige nummer af PASSAGE havde Hölderlin som tema, og indeholdt $i$ den anledning Per Aage Brandts oversættelse af "Brot und Wein". Denne oversættelse adskiller sig afgorende fra og er dermed en kommenterer til Thorkild Bjørnvigs oversættelse af samme digt fra Brød og vin og andre digte.

I "Den akademiske Hölderlin, den filosofiske og den digteriske" og $i$ "Metriske meditationer" redegør henholdsvis Thorkild Bjørnvig og Per Aage Brandt. for de præmisser, der styrer deres respektive oversættelser. Hvor forestillingen om den 'korrekte' oversættelse er fælles for de to forste indlæg, da drejer Jørn Erslev Andersens "Mellem linierne" sig om oversættelsen om en fortolkende praksis, hvor hver enkelt oversættelse også er en interpretation af 'originalen', her "Brot und Wein".

Endelig kunne også efterårets reviderede genudgivelse Brød og vin og andre digte på Gyldendal være anledning til endnu en gang at åbne sporgsmålet om Hölderlin.

Redaktionen 


\title{
BRØD OG VIN
}

\author{
Til Heinze
}

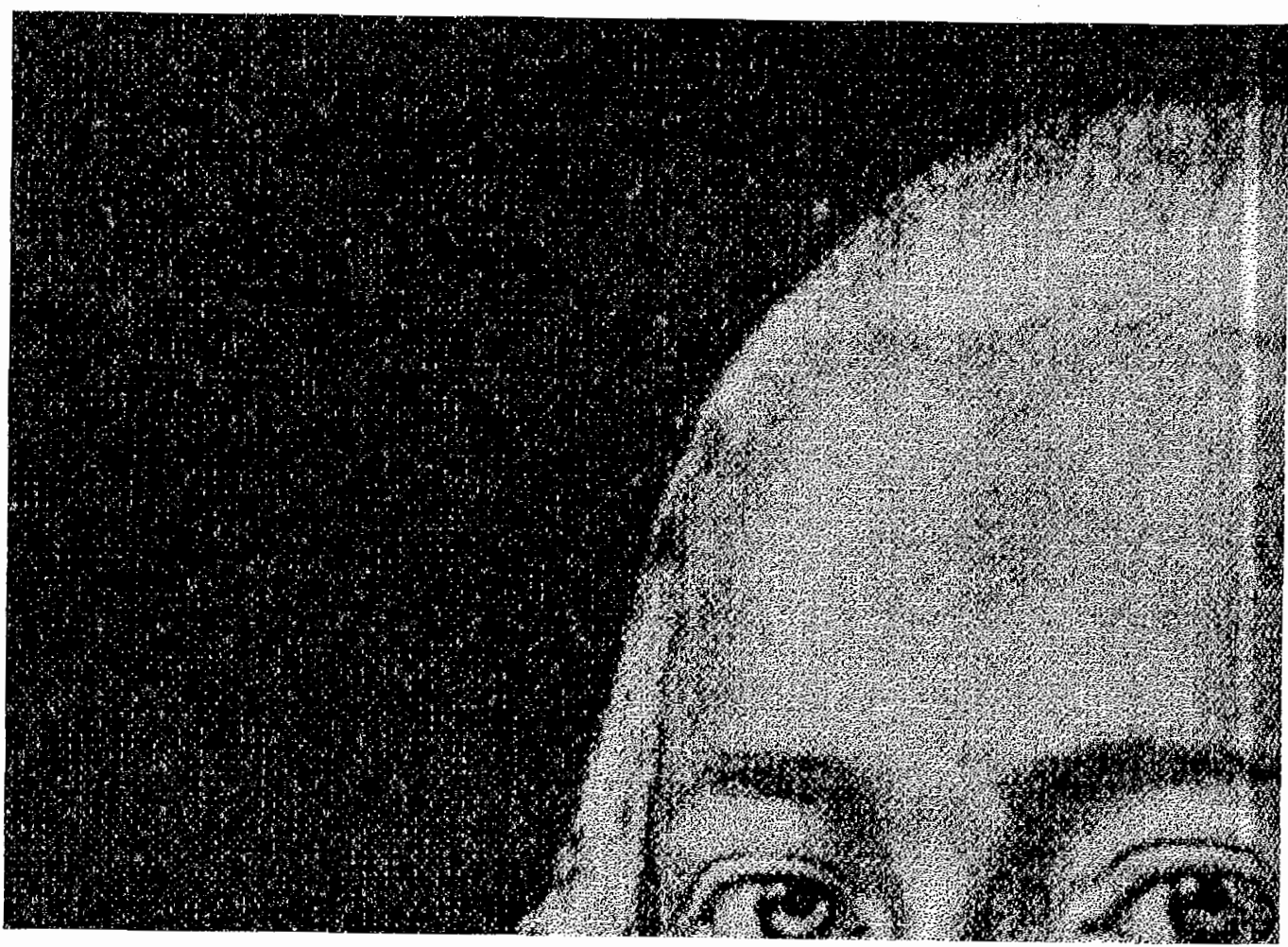

1

Rundtom hviler min by; tavs ligger den oplyste gade, og, med faklerne tændt, bruser nu vognene bort. Mætte af dagens glæder går folk til ro, og et tænksomt hovede vejer tilfreds dagens gevinst og tab

op mod hinanden derhjemme; tomt står for druer og blomster og fra hændernes værk hviler det travle torv.

Men fra haverne toner et strengespil fjærnt; måske en elskende spiller der eller en ensom mand

husker på fjærne venner og ungdomstiden; bestandig vældende bruser hver brønd frisk ved det duftende bed.

Dæmpet i dæmringsluft bredes lyden fra svingende klokker og, kommet timen i hu, råber en vægter dens tal.

Nu kommer også en luftning, bevæger de øverste kroner henne i lunden; vor Jords skyggebillede, se!

månen kommer nu også; den sværmeriske, natten kommer, af stjerner fyldt, lidt kun bekymret om os, går den forbavsendes lysglans, hun, iblandt mennesker fremmed, op over bjergenes ryg sorgfuldt og prægtigt frem.

\section{2}

Underfuld er den højtophøjedes gunst, og ingen véd hvad der overgår én ved hende og hvorfra det sker. Sådan bevæger hun verden og menneskers håbende sjæle, selv ingen viis forstår, hvad hun bereder, det vil nemlig den øverste gud, som elsker dig meget, og derfor står dig langt mere, end hun, nær den besindige dag. Dog undertiden sker det, at skyggerne elskes af klare øjne, som prøver af lyst søvnen, før de er nødt, eller en trofast mand ser gerne langt ind i natten, ja, vi bør vi hende sang, vi hende kranse, fordi natten er helliget alle de vildfarne, alle de døde, medens hun selv består, evigt, i frieste ånd. Men hun må også, så vi i det tøvende tidsrum, i mørket ejer en smule fast, noget som holder, trods alt, unde os glemslen, det helligtberuste, unde os ordet, 
strømmende, søvnløst og fyldt, ligesom elskende er skænke mer fyldte pokaler, mer dristigt liv, og hellig

magt til at huske så vi usvækket våger ved nat.

Dertil: forgæves skjuler vi hjertet i brystet, forgæves båndlægger vi vort mod, mestre og svende, thi hvem kunne vel hindre det, hvem kunne forbyde os glæden? Ja, og guddommelig ild driver ved dag og ved nat tilmed til opbrud. Så kom! at vi kan skue det åbne,

søge det dybest, det mest egne, så fjernt det end er.

Fast står et: lad det være ved middag, være ved midnat, altid består noget rent målende, altid et mål,

fælles for alle og dog er enhver hans eget beskåret,

dérhen går da enhver, kommer hvorhen han kan.

Derfor! og lad kun det jublende afsind med spot ramme spotten, når det den hellige nat griber sin sanger med eet; derfor kom da til Istmos, hen hvor det åbne hav bruser nær ved Parnassos og sne skinner om Delfis fjeld, dér i Olympos land, ja, der på Citærons højder,

dér, hvor gran står ved gran, under de druer hvorfra

Thebe nedbruser og Ismenos strømmer i Kadmos land, th dérfra kommer og bagud peger den kommende gud.

Salige Grækenland! du hus for de himmelske, altså er det dog sandt hvad engang vi i vor ungdom har hørt? Festlige sal! havet er gulv! og bjergene borde,

bygget i ældgammel tid sandelig kun til eet brug!

Men hvor er tronerne, templerne? Karrene, hvor er de henne

hvor er med Nektar fyldt sangen til gudernes lyst?

Hvor, hvor lyser de da, de vise fjerntrammende lovsprog?

Delfi sover og hvor toner det vældige lod?

Hvor er det hurtige? bryder med lykkens altfyldende nærvær

ind over øjnene højt tordnende ned fra det blå?

Fader Æter! kaldte og fløj det fra tunge til tunge

tusindfold, ingen bar livet alene og tavs;

delt er dets fylde en fryd, udvekslet med fremmede opstår

jubel, sovende gror ordet, øges dets magt

Fader! muntert! og runger, så langt hen det rækker, tegnet,

ældgammelt, fædrenes arv, rammende skabende ned.

Således kommer de himmelske, sådan, fra skyggerne ned blandt mennesker, uhyre sindsrystende, når deres dag.
Ufølt kommer de først, thi børnene sætter sig mod dem alt for klar kommer lykken, alt for blændende stærk

mennesket ængstes og knap ved en halvgud at sige ved navne

hvem der træder ham nær, bringer ham gaverne nu.

Modet fra hine er dog stort, déres glæder fylder

hjertet, knap at han ved brugen af godet han får,

skaber, og ødsler, uhelligt, det blev ham næsten helligt

blot af hans signende hånd dåremildt, godhjertet rørt.

Mest muligt tåler de himmelske dette, så kommer de selv i

sandhed og mennesket blir vant til lykke og dag,

vant til at skue de åbenbare, at se deres ansigt,

de som breder, forlængst benævint det ene og alt,

dybt i det tavse bryst opfyldelsens frihed, de som

først og alene har saliggjort alle begær;

sådan er mennesket; er det der, godet, drager en guddom

omsorg med gaver for ham; ser han det ikke engang.

Først må han bære; men nu, nu gir han hvad mest han elsker navn og nu må da ord opstå, som blomster, for dét.

Nu har han tænkt for alvor at ære de salige guder,

virkeligt, sanddru må alt samle sig om deres pris

Intet tør skue lyset, som ikke behager de høje,

ikke for æteren ske ørkesløst dumpe forsøg.

Derfor for værdigt at stå i de himmelskes nærvær, rejser

folk ved folk sig i ny herlige ordninger, rankt

mellem hinanden og bygger sig skønne templer og byer

fast og ædelt, går højt over hver tilvant bred

o, men hvor er de? Hvor blomstrer de velkendte, festernes kroner?

Theben forgår og Athen; er da hver våbenlarm nu

endt i Olympia, hint brus af de gyldne vognes kampspil

kranses de slet ikke mer skibene fra Korint?

Hvorfor er de nu tavse, de hellige gamle teatre?

Hvorfor sluttet hver fryd, vakt af den viede dans?

Hvorfor mærker, som ellers, en gud ikke mandens pande,

stempler den trufne, som før. Eller han kom også selv,

påtog sig menneskets skikkelse, vandred hernede tilsidst og

fuldendte, slutted med dyb trøst den himmelske fest.

Men vi er kommet for sent, ven! Ganske vist, guderne lever,

men over hodet på os $i$ andre verdner end vor.

Endeløst virker de der og synes lidt kun at agte 
på om vi lever, så dybt skåner de himmelske os.

Thi ikke altid formår et svagt kar at rumme dem, kun til

tider kan mennesket helt bære et guddomsfyldt liv.

Drøm om dem er da siden vort lod. Men fejlspor, forvirring

hjælper som hvile og søvn, nøden og natten gør stærk

indtil at helte nok er vokset $i$ jernhårde vugger,

hjerter, som ligner i kraft himmelske, ligesom før.

Tordnende kommer de da. Mens synes jeg ofte at søvn er

bedre end her uden een ligesindet at gå,

vente så bønligt og hvad jeg skal gøre så længe og sige

ved ikke jeg og hvortil digter i karrig tid?

Men de er, har du sagt, som vingudens hellige præster

der i den hellige nat vandred fra land til land.

Dengang de alle, for nogen tid siden, os synes det lang tid, alle steg opad, som her lyksaliggjorde vort liv,

dengang da Faderen vendte sit ansigt fra mennesker, og med rette begyndende sorg skred over jordkredsen, da

sås som den sidste en stille genius himmelsk trøstfyldt varsle den store dags ende, før han forsvandt,

efterlod som et tegn på, at det havde været og kom her atter, det himmelske kor da nogle gaver, som vi

evned at glæde os over, som ellers, på menneskers måde,

for til at glædes, med ånd, blev os det større for stort, endnu fattes de stærke til højeste glæder, dog mellem

mennesker lever endnu stille en smule tak.

Brød er vel Jordens frugt, dog er det signet af lyset

og fra den tordnende gud kommer al vinens fryd.

Derfor tænker vi også ved dem på de himmelske, som har

været her før, som igen kommer til rigtig tid,

derfor besynger de også med alvor, sangerne, vinens

gud, ikke goldt udtænkt toner den gamles pris.

Ja, de siger med rette, han udsoner dagen med natten, fører stjernernes løb evigt ned, evigt op

glad bestandig, som grenværk på stedsegrønnende graner, som han har kær, og den krans, han af vedbend har valgt, netop fordi han forbliver og bringer de flygtede guders

spor ned til gudløse der, hvor nu mørket er tæt.

Det, som de gamles sang har forudsagt guds børn, stemmer, se! det er os, vi er selv blevet Hesperiens frugt!

Underfuldt og nøjagtigt er det på mennesker opfyldt, du, som har prøvet det, tro! men så mange ting sker, ingenting virker, vi har intet hjerte, er skygger, til Æteren:

Faderen! fatter enhver, hører os alle til.

Dog imens kommer som fakkelsvinger søn af den højeste, syrieren, herned mellem skyggerne selv.

Salige vise ser det; et smil fra den fangne sjæl skinner,

og for det rolige lys tøer deres øjne op.

Blidere drømmer og sover Titanen $i$ Jordens favn, selv

Cerberus, nagfyldt, selv den, drikker og sover dybt.

Oversat af Thorkild Bjørnvig 